\title{
DEVELOPMENT OF SAWARNA BEACH TOURISM OBJECT THROUGH ESTABLISHING CITY BRANDING
}

\author{
Nur Kholisoh \\ Universitas Mercu Buana Jakarta, Indonesia
}

\begin{abstract}
Sawarna Tourism Village is a tourist village in Bayah Sub-District, Lebak District, Banten. The village area is directly bordered by the Indian Ocean, and therefore, it is in a coastal area. Of 204 tourism objects in Banten Province, the charm of the beauty of Sawarna Beach tourist destination has its own magnetism for tourists. The beach beauty located in Bayah Subdistrict, Lebak is called as "Little Paradise" by foreign tourists from European and American countries and Australia particularly who like surfing. The location is far from the downtown and therefore, media access in Sawarna Village and its surroundings is relatively difficult. So far there are a few mass media whether they are print or electronic media that cover the natural beauty in Sawarna Village. This certainly affects the development of Sawarna beach tourism object as one of the mainstay tourist destinations in Banten Province. As a tourist object, Sawarna Beach is as good and attractive as similar tourist objects in Indonesia, such as those in Bali and Lombok. An important issue that Banten Provincial government should make the big concern relates to the City Branding Development. After participating in this counseling, it aims that Sawarna Villagers know and understand the importance of establishing the city branding to develop their beach tourism objects. Moreover, it is expected to empower the villagers around the Sawarna beach and therefore, it will increase their income.
\end{abstract}

Keywords: Tourism Object, Sawarna Beach, City Branding

\section{Introduction}

Sawarna Tourism Village is a tourist village in Bayah Sub-District, Lebak District, Banten Province. The Sawarna Village has directly border to the Indian Ocean, and therefore, it is a coastal area. White sandy beaches with rugged coral reefs alternately makes the Sawarna Village coast full of beauty. Stretching from Pulo Manuk beach on the west side to Karang Taraje beach on the east side, the landscape offers various amazing views. Due to face to face with the Indian Ocean, the waves in Sawarna invite many surfers to make surfing on the top of the waves that are chasing each other towards the beach.

Of the 204 tourism objects in Banten Province, the enchanting beauty of the Sawarna Beach Tourist Destination has its own magnetism for tourists. Foreign tourists from European countries, USA and Australia who like to surfing call the beauty of the beaches located in Bayah Sub-District, Lebak District as "Little Paradise".

Every year when summer arrives, hundreds of foreign tourists come to Sawarna. The just have fun enjoying the waves of the Indian Ocean. Aside from the clean sea and high tiered waves, the natural panorama around Sawarna Bay is also very beautiful. They can also carry out safari along the beach to see tourist objects, such as Tanjung Layar and the Kabayan site. For tourists who want to enjoy the natural panorama of the mountains can carry out safari to Halimun National Park or they can go the mysterious natural cave around the Sawarna Village. According to the existing data, there are about a dozen natural caves that many tourists have had visited, including Lalai Cave, Lauk Cave, and caves that were once inhabited by ancient humans.

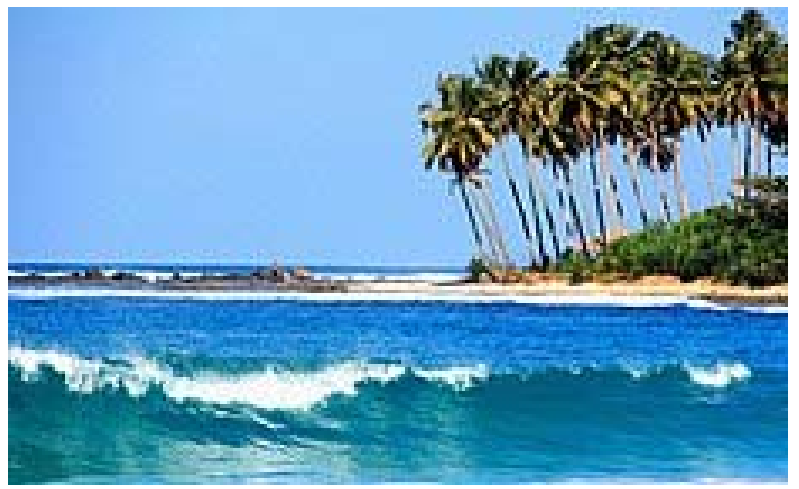


Historically, the existence of The Sawarna Village closely relates to the role of Lean Louis Van Gough. Around 1907 Jean Louis opened a 54-hectare coconut plantation located on the edge of Ciantir and Tanjung Layar beaches. He employed many native workers from outside Banten but they remain in Java due to the village which was still a wild forest. Along with population growth through time, the community was called Sawarna. However, due to differences in accent, dialect and colloquial language, Sawarna is interpreted from Sundanese language, i.e. "Sorana" and it means his voice.

Moreover, there is another version of the origin of the Sawarna name. Sawarna comes from the name of Swarna whose lived in the 1900s and he was the elder and the first person as head of The Sawarna Village. Swarna literally means Sawarna. Sawarna is derived from the Sundanese language and it means one color. It is the reason why the beautiful coastal village is called Sawarna and it signifies that the residents of that location are of one color, i.e. Sundanese people of Banten.

Along the time, The Sawarna Village has metamorphosed from a coconut plantation to a tourist village. We can easily find a variety of "homestays" or rent houses for tourists. The village is located between the coconut plantation and rice fields. These conditions make tourists want to linger in the tourist village. Various tourism activities are offered to domestic and foreign tourists, among others:

\section{Sawarna Surfing}

Surfing can be carried out at Ciantir Beach well known for its white sand and rocky beach. Ciantir Beach is located 600 meters from the entry post in Cikaung Hamlet. The location can be reached within around 7 minutes by motorcycle and 20 minutes on foot.

\section{Swimming}

Swimming can be carried out at Pasir Putih Beach. It is located 500 meters from the entry post and it can be reached within 6 minutes by motorcycle and 15 minutes on foot. Legon Pari Beach is a pleasant place to swim. The location of Legon Pari Beach is taken from a lane beside Elementary School SD Sawarna with the distance of 2 kilometers from the entry post. It can be reached within 15 minutes by motorcycle and 45 minutes on foot.

\section{Sunset dan Sunrise in Sawarna}

Other activities are sunset seeing from Tanjung Layar Beach and it is located 1 kilometers from the entry post in Cikaung Hamlet, and can be reached within 10 minutes by motorcycle and 20 minutes on foot. Other interesting locations to see the sunset seeing are at Pasir Putih Beach and Ciantir Beach. The two beaches are located in Cikaung Hamlet. Meanwhile, we can see sunrise at Legon Pari Beach, Karang Taraje Beach, and Karang Bereum Beach in Leles Hamlet.

\section{Cave Tracking}

Trekking and cave tour activities can be carried out at Lalay Cave. It is located around 2 kilometers from the entry post of the tourist object in Cipanas Hamlet. The trip can be reached in 10 minutes by motorcycle and 40 minutes on foot. The entrance fee is around Rp. 5,000 and the authority has provided equipment for exploration such as helmets and flashlights.

\section{Village Tourism}

Village tourism activities can also be carried out. In The Sawarna Village, tourists can see the daily life of the villagers. They can see rice field and plantation. Moreover, they can visit the centers of home industry to see and participate in the process of making crafts from coconut shells, batik, bananas sale, and recycled craftsmanship.

\section{Research Problem}

The Sawarna Village is located about $230 \mathrm{~km}$ from Greater Jakarta. The journey to this village we can reach with private or public transportation. To get to Sawarna Village, we can spend about 6-7 and 9-10 hours traveling with private and public transportation consecutively. Firstly, tourists can use KRL Commuterlines from Greater Jakarta to Bogor Station for around 2 hours traveling. From Bogor Station to Baranangsiang Terminal they can use public transportation. From Baranangsiang Terminal to Pelabuhan Ratu they can use MGI Bus with 5 hours traveling. From Pelabuhan Ratu to Sawarna Village they can reach the location around 2 hours traveling using ELF. 
The location of The Sawarna Village is far from the downtown and access media in Sawarna village is relatively difficult. So far there is a few mass media either print or electronic ones that cover the natural beauty of the Sawarna Village. This certainly affects the development of Sawarna Beach Tourism Object as one of the mainstay tourist destinations in Banten Province. As a tourist attraction, The Sawarna Beach is as good and attractive as other similar tourist objects in Indonesia, such as in Bali and Lombok. One of the important issues that becomes the concern of the Banten Province government relates to City Branding.

There are several issues that become the focus of attention in this community service program, i.e. :

1. How does Sawarna Village establish its own community image?

2. How is the community image of Sawarna Village?

3. How to develop Sawarna Beach Tourism Objects and therefore, these are widely well known and always remembered as one of the most popular tourist destinations?

\section{Solution}

All this time, Sawarna Village is widely well known in the level of domestic and foreign tourists, particularly for its beautiful beach tourism. The tourists can enjoy various attractions offered. Right now travel agents from outside Sawarna Village offer different tour packages for vacation to Sawarna Village. Despite the Sawarna Village Administration manages Sawarna Tourism Objects, it does not yet have and directly sell the tour packages. Through the Bank Indonesia Social Program, the Banten representative office has begun the process of management evaluation and improvement towards the Sawarna Village tourism management and it will be handle by a professional institution under the Regional Government. Efforts are being made to improve BUMDes (Village-Owned Companies) which will be proposed to manage tourism objects in the Sawarna Village.

An overview of the tourism packages that can be offered in the Sawarna Village include among others:

- Beach Tour Packages: Tourists are offered to visit a series of beaches in The Sawarna Village such as, Pasir Putih Beach, Tangjung Layar Beach, Legon Pari Beach, Pulo Manuk Beach.

- Village Tour Packages: besides visiting the beaches in The Sawarna Village, tourists can also visit the center of handicraft and snack industry such as recycled souvenirs, Sawarna batik, coconut shell carvings, bananas sale and chips.

- Adventure Tour Packages: Besides the white sand beaches, The Sawarna Village also has caves to be explored. The tour packages can consist of beach and cave exploring tours.

- Photography Tour Packages: Some of the beach locations in The Sawarna Village are reefs, such as Karang Bokor Beach, Taraje Beach, Karang Bodas Beach. This tour package is particularly for photographers who are usually most interested in capturing the beauty of these steep rocky beaches.

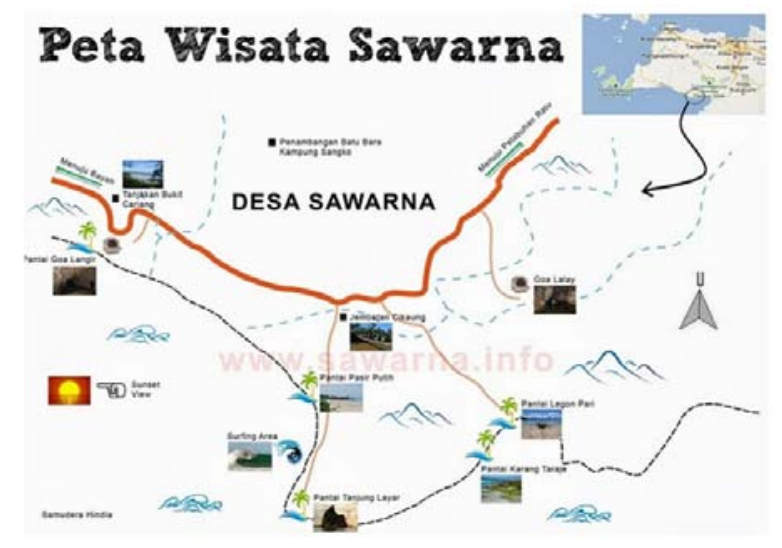

Sawarna villagers are multi-ethnic, such as Bantenese, Sundanese and Javanese. It is because most of the coconut plantation workers with Javanese ethnicity in the Sawarna village were brought in from Central Java and East Java Province. Most of them have professions as farmers, craftsmen, rice field workers, laborers, and traders. However, since the Sawarna Village begins to be known among local and foreign tourists, many residents also have a side profession as a tour guide.

The work and profession of Sawarna residents will be better if the existing potential tourism can be developed even better. Their work as a tour guide can also be more empowered and it will increase their income and standard of living. For this reason, it is necessary to make various efforts in the level of the community and the local government including by establishing good City Branding. Therefore, the tourism object of the Sawarna Village can become a mainstay tourist destination and is of public interest in domestic and international level. 


\section{Output Target}

After participating in this counseling, it is targeted that Sawarna Villagers know and understand the importance of establishing the city branding for the developoment of Sawarna Beach Tourism Objects. Moreover, the counseling is expected to empower residents around the Sawarna Beach and therefore, it will increase their income.

Another target of the counseling is scientific publications in the ISSN journals or proceedings concerning community service. This publication has to be carried out, and so, society in general knows the importance of establishing the city branding in an effort to develop tourist objects in Sawarna Beach. Moreover, through publication it is expected that society in general can also know and understand how to form a city branding as a way to develop a tourism object.

Besides the publication in the ISSIN scientific journals or proceedings, the results of this community service program will be published in online media and used as the ISBN books. On the other hand, it can be further processed to obtain the Intellectual Property Rights (IPR). Therefore, it is expected that it can be applied to society in general, particularly among people who are in Sawarna Village, Lebak District, Banten Province.

\section{Implementing Methods}

This counseling uses several methods or methods, i.e.: discussion, presentation and oration. The discussion in the form of small groups (Focus Group Discussion / FGD) is carried out and the participants are divided into several small groups to discuss some themes or issues that the tutors raise particularly those related to the importance of establishing city branding to develop Sawarna Beach Tourism Objects. After completing the discussion, the representatives of each group present the results of their group discussions alternately and these will get response from other discussion groups.

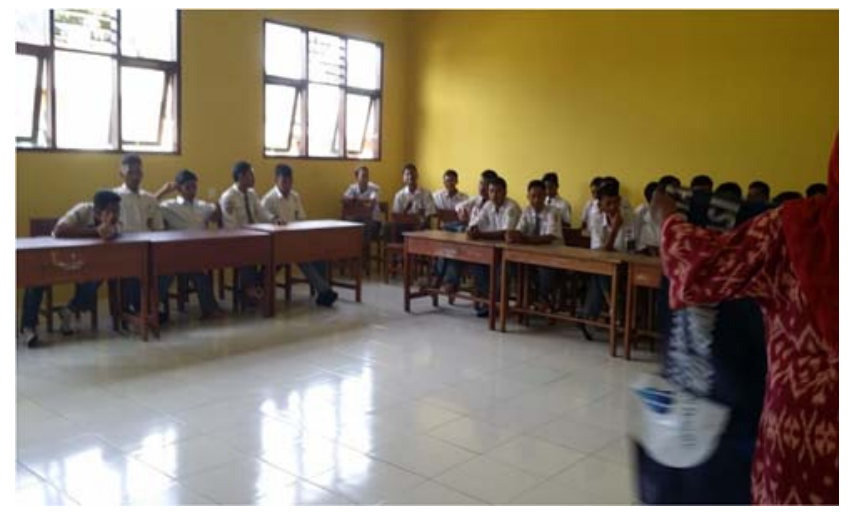

Moreover, the results of the focus group discussion (FGD) will be discussed in the level of the tutors. They will give directions and explanations through oration techniques. In this discussion, the tutors deliver the main material about the importance of establishing the city branding for the development of Sawarna Beach Tourism Objects. Moreover, it also discusses the community empowerment around Sawarna Beach in the form of city branding for the development of Sawarna Beach Tourism Objects. To further clarify and provide a good understanding of the materials presented in the FGD, the turors give examples relating to city branding on social media.

\section{Results and Discussion}

According to Kotler (2006: 3), branding concerns about bringing something ordinary ones and making them more worthy and valuable in a such ways. When talking about brands, some people will immediately remember Coca Cola, Apple, Nokia, Rinso or Aqua. Some of these brands are also frequently quoted in the business to consumer sector. For a company, the brands represents a strong and enduring asset, and it will become a trigger for true value that has increased the company's success. The business communication think a city like a product. For the city to have high value and become an investment, tourism or visit destination, a city must have a good image. The city image itself can be interpreted as a mental picture of the city in accordance with average view of its citizens (Zahnd, 1993). Moreover, Keith Dinie explains that city branding does not only relate to identity but also city attributes, the collaboration between public and private sectors and the sustainability of the brand itself both in terms of marketing and real conditions.

In Sawarna itself there are nine tourist locations that tourists can visit. These include: Taraje Reef, Legon Pari, Karang Bereum, Tanjung Layar, Pasir Putih, Goa Lalay, Goa Langir, Karang Bokor, and Pulo Manuk. The beaches are beautiful. Many local and foreign tourists from various countries frequently visit them. 
Foreign tourists like its high waves and becomes popular among them for surfing activities. However, the natural beauty in Sawarna Village does not get support from other supporting factors, such as poor road access for excessive road damage and lack of public road lighting. For this reason, the counseling must be carried out so that local people are able to make Sawarna Beach tourism objects better. Furthermore, some of the tourism attractions in Sawarna Beach can be better developed for the positive branding of Sawarna Beach Tourism Objects. Here some tourism objects of Sawarna Village Beach.

The presence of Sawarna Beach located in Sawarna Village, Bayah Sub-District, Lebak District becomes the tourism symbol in Lebak District. Due to a famous tourist village area for a long time, Sawarna Village has become an idol for foreign tourists. The tourism object is located at the end of Lebak Multatuli City, and it has natural wonders. On the beach there is Tanjung Layar and it is two rocks standing tall on the beach. Besides the hanging rock, there is also Legon Pari Beach and other tourism objects.

To develop a good city branding for Sawarna Beach as a tourism object and attractions, it is necessary to consider several things, such as easily accessible locations. From the downtown of Banten, you only have to take four hours to get to Sawarna. Moreover, it can take five hours from Greater Jakarta, and one hour from Sukabumi. Tourists will enjoy the natural beauty, culinary and can take rest while they stay in a community homestay. Moreover, they can enjoy the beauty of a waterfall made of rocks that border to the beach.

Moreover, it provides attractive tourism packages. Right now there are attractive tourism packages for vacation to Sawarna Village that travel agents from outside Sawarna Village widely offer. As the Sawarna Tourism Management, The Sawarna Village Government does not yet have and directly sell attractive tourism packages. Through the Bank Indonesia Social Program, the Banten representative office has begun the process of management evaluation and improvement of the Sawarna Village tourism management under a professional institution of the Regional Government. Efforts to improve the BUMD are being carried out and it will be proposed to manage tourism in the Sawarna Village. The description of attractive tourism packages that can be offered in Sawarna Village includes:

- Beach Tour Packages: Tourists are offered to visit a series of beaches in Sawarna Village such as, Pasir Putih Beach, Tangjung Layar Beach, Legon Pari Beach, Pulo Manuk Beach.

- Village Tour Packages: besides visiting the beaches in Sawarna Village, tourists can also visit the centres of handicraft and snack industry such as recycled souvenirs, Sawarna batik, coconut shell carvings, sale bananas sale and banana chips.

- Adventure Tour Packages: Sawarna Village has white sand beaches and caves that tourists can explore. The tour packages can cover beach and cave exploring tours.

- Photography Tour Packages: Some beach locations in Sawarna Village are coral reefs, such as Karang Bokor Beach, Karang Taraje Beach, Karang Bodas Beach. This tour package is specifically for photographers who are definitely most interested in capturing the beauty of these steep rocky beaches.

\section{Conclusion and Suggestions}

There are several conclusion points from the training of "Development of Sawarma Beach Tourism Object through Establishing City Branding", i.e.: Lebak District Tourism Office (Dispar) will develop 25 local tourism destinations. The program is a step that Lebak District Government carries out to increase the community economic growth and poverty and unemployment reduction. The potential tourism can be developed because it has its own charm of beauty and so, it can attract domestic and foreign tourists. Some potential tourist attractions around the world are the cultural tourism of the Baduy community and Sawarna Beach. The excellence of the cultural tourism destination of the Baduy community is due to the maintenance of their ancestral customs and their rejection of modern life. In fact, the cultural tourism is popular among many researchers from various countries and foreign universities.

Moreover, Sawarna Beach tourism is very suitable for surfing activities due to quite large waves. The beach directly borders to the Indian Ocean. All this time, many foreign tourists visit Sawarna Beach. In addition to carry out surfing activities, they also enjoy the natural panorama along the south coast of Lebak District. The regional government is developing a shopping center in the village tourism location, and it is expected to be the backbone of people's income. The village tourism area can grow community craft business centers and it will become value added for local people's welfare. From the training "The Tourism Object of Sawarma Beach Through Developing City Branding", there are some results that the implementation team can suggest, i.e. improving facilities and infrastructure that are more comfortable for local and foreign tourists.

\section{References}

Arifin Anwar, (1998) Ilmu Komunikasi : sebuah Pengantar Ringkas, Rajawali Press, Jakarta Devito, Joseph A, (1997) Komunikasi Antar Manusia - Kuliah Dasar, e.d. Ke-5, Professional Books, Jakarta Fahrudin, Adi, (1994). Pemberdayaan, Partisipasi dan Penguatan Kapasitas Masyarakat. Bandung: Humaniora. Lord, John dan Peggy Hutchison, (1993) E Process of Empowerment: Implications for theory and Practice, 
Canadian Journal of Community Mental Health, 12: 1.

Mc. Quail, Dennis Sven Windhal, (1996) Communication Models, Longman Inc, USA

Mulyana Deddy, (2000) Ilmu Komunikasi suatu Pengantar, PT Remaja Rosdakarya, Bandung

Paul, R. Wayne, J Don F, (2000) Komunikasi Organisasi (Editor : Deddy Mulyana, M.A., Ph. D) PT Remaja Rosdakarya, Bandung.

Sandjaja, Sasa Djuarsa, (1993) Pengantar Komunikasi, Univeristas Terbuka, Jakarta.

Sulistiyani, A. Teguh dan kawan-kawan, (2017) Proses Pemberdayaan Masyarakat Desa Sitimulyo, Kecamatan Piyungan, Kabupaten Bantul dalam Pembentukan Kelompok Pengelola Sampah Mandiri, Indonesian Journal of Community Engagement, Vol. 02, No. 02.

Wilonoyudho, Saratri, Model Pemberdayaan Masyarakat dalam Pengendalian Banjir yang Berwawasan Lingkungan di Semarang, Jurnal Manusia dan Lingkungan, Vo. 16. No. 2, Juli 2009. 